American Journal of Environmental Sciences 7 (6): 531-533, 2011

ISSN 1553-345X

(C) 2011 Science Publications

\title{
Determination of Lead in Soil along the Highways of Kosova
}

\author{
Albert Maxhuni, Fatmir Faiku, \\ Musaj Pacarizi, Melos Zeka and Valbone Mehmeti \\ Department of Chemistry, Faculty of Natural Sciences, \\ University of Prishtina, Mother Tereza Street 5, 10000 Prishtine, Kosova
}

\begin{abstract}
Problem statement: During recent several decades soil was polluted more and more serious by heavy metals because of mining, smelting, irrigating with sewerage and some other human activities. These heavy metals may adversely affect soil ecology, agricultural production or product quality and ground water quality and will ultimately harm to health of mankind by food chain. Approach: We had analyzed the quantity of Lead in two different highways Prishtina-Skopje (near the Ferizaj) and in Prishtina-Gjilan (near the Artane), Kosova. The samples were taken in different distance from routs. Results: The quantity of lead near the highways is very higher. Away from routs the quantity of lead decreases significantly. The quantity of Lead in highway Prishtina-Skopje is higher than in highway Prishtina-Gjilan. Conclusion: If the pollution with lead continues, then in future we will have very danger ecosystem problems. For that is time to do something in way to eliminate this kind of soil pollution and to improve the existing state.
\end{abstract}

Key words: Soil analysis, environmental problems, atomic absorption spectroscopy

\section{INTRODUCTION}

Metal contamination and pollution in the environment, the significance of biodiversity conservation and the root causes of biodiversity loss are emphasized in a wide array of works. Global industrialization and human social and agricultural activities have an effect on environmental pollution and the global ecosystem (Savran et al., 2011). This corruption of the ecosystem has a negative effect on human health and on all living organisms. Growing industrialization and environmental pollution from technology have started to affect human health.

Pollution of the environment with toxic metals has increased dramatically since the onset of the industrial revolution. Heavy metal contamination in soil is a major concern because of their toxicity and threat to human life and the environment (Akan et al., 2009; Nriagu, 1979).

Soil pollution is one of the common environmental problems and their investigation depends on chemical analyses (Cances et al., 2003; Ge et al., 2005).

Soils accept high quantity of polluted products every year. More of $\mathrm{SO}_{2}$, emitted during burning of carburetor which contain sulfur, back to the soil as sulfate. Atmospheric nitrogen oxides can transform to the nitrate, which than they can deposits on the soil (Lee et al., 2006).

Heavy metals are being enriched in all aspects of the environment, viz., air, water and soil, by anthropogenic as well as natural processes. Soil pollution by heavy metals, such as cadmium, lead, chromium, copper and arsenic is a problem of concern (Oprea et al., 2010; 2011). Although heavy metals are naturally present in soil, contamination and comes, from local sources: mostly industry (mainly non-ferrous industries, but also power plants and iron, steel and chemical industries), agriculture (irrigation with polluted waters, sewage sludge and fertilizer, especially phosphates, contaminated manure and pesticide containing heavy metals), waste incineration, combustion of fossil fuels and road traffic. Long-range transport of atmospheric pollutants adds to the metals in the natural environment (Alloway, 1994; Davis et al., 1992).

Lead is considered one of the environmentally hazardous elements because, along with cadmium, mercury, copper, zinc and chromium it poses a particularly high risk of disturbing the chemical balance in the ecosystem (Jankiewicz et al., 2001; Jaunakais et al., 2010).

During burning of carburetor from cars, near highway are founded Lead in very higher concentration. For that is very interesting to know the concentration of Lead near the highway. We have done some experiments in two different highways in Kosova and we found the high quantity of Lead near these routes.

Corresponding Author: Albert Maxhuni, Department of Chemistry, Faculty of Natural Sciences, University of Prishtina, Mother Tereza Street 5, 10000 Prishtine, Kosova 


\section{MATERIALS AND METHODS}

All chemicals used were of analytical grade and were used without further purification.

The primary soil samples were collected according to a standard procedure by means of a soil rod at depth 20-30 cm. Samples are taken in different distances as we can see from diagrams. Final samples were prepared according to standard procedure. Prior to mineralization the soil was brought to the state of "air dryness" by leaving the samples for two weeks in a dry and wellventilated place. The samples (about $2.0 \mathrm{~g}$ ) were mineralized in a microwave mineralizer using nitric acid. The hot solution was filtered into $50 \mathrm{~mL}$ measuring flasks and water was added to the mark.

For the determination of lead in soil (Mielke, 1999) we used the AAS in 283.3 wavelengths, in concentration scale $0.005-1 \mathrm{mg} \mathrm{L}^{-1}$ and in detection limit of $0.001 \mathrm{mg} \mathrm{L}^{-1}$. Atomization time was from 10 sec in $2700^{\circ} \mathrm{C}$. From standard solution of Lead are prepared working standard solution with concentration of $0.5 ; 10 ; 15$ and $20 \mu \mathrm{g} \mathrm{mL}^{-1}$.

\section{RESULTS}

Contamination of soil with Lead every year increase and it is a very danger for our environment. We have analyzed the quantity of Lead near routes and these results we show on Table 1 and 2.

Table 1: Lead concentration in samples taken near the highway Prishtina-Skopje (Ferizaj), Kosova

\begin{tabular}{lcc}
\hline Sample & $\begin{array}{l}\text { Distance from } \\
\text { routes } / \mathrm{m}\end{array}$ & $\begin{array}{c}\text { Quantity of } \\
\mathrm{Pb} / \mathrm{mg} / \mathrm{kg}\end{array}$ \\
\hline 1 & 5 & 173.7 \\
2 & 10 & 170.7 \\
3 & 20 & 129.1 \\
4 & 30 & 113.2 \\
5 & 50 & 103.3 \\
6 & 100 & 78.8 \\
7 & 500 & 32.9 \\
8 & 700 & 28.6 \\
9 & 1000 & 21.9 \\
10 & 1500 & 19.4 \\
\hline
\end{tabular}

Table 2: Lead concentration in samples taken near the highway Prishtina-Gjilan (Artane), Kosova

\begin{tabular}{lcr}
\hline Sample & $\begin{array}{l}\text { Distance from } \\
\text { routes/ } \mathrm{m}\end{array}$ & $\begin{array}{c}\text { Quantity of } \\
\mathrm{Pb} / \mathrm{mg} / \mathrm{kg}\end{array}$ \\
\hline 1 & 5 & 43.7 \\
2 & 10 & 42.5 \\
3 & 20 & 39.1 \\
4 & 30 & 33.3 \\
5 & 50 & 28.4 \\
6 & 100 & 26.3 \\
7 & 500 & 23.4 \\
8 & 700 & 19.4 \\
9 & 1000 & 4.9 \\
10 & 1500 & 1.9 \\
\hline
\end{tabular}

\section{DISCUSSION}

From our experiments we can see that the amount of Lead depends on distance from routes. The quantity of Lead in highway Prishtina-Skopje (in Ferizaj) is very higher. Quantities of Lead in distance from 5-1500 m are from 173.7-19.4 mg kg-1 (Fig. 1). The mindsets quantity is $87.16 \mathrm{mg} \mathrm{kg}^{-1} \mathrm{~Pb}$.

The quantity of Lead in highway Prishtina-Gjilan (in Artane) is lower and it is from $43.7-1.9 \mathrm{mg} \mathrm{kg}^{-1}$ and has mindsets quantity of $26.25 \mathrm{mg} \mathrm{kg}^{-1}$ (Fig. 2).

As we can see in all samples we found high quantity of Lead. The quantity decreases away from highway. So the fields near highway are more polluted with Lead. The quantity of Lead in samples which we have taken near highway Prishtina -Skopje (in Ferizaj) are more polluted than samples take in highway Prishtina-Gjilan (in Artane).

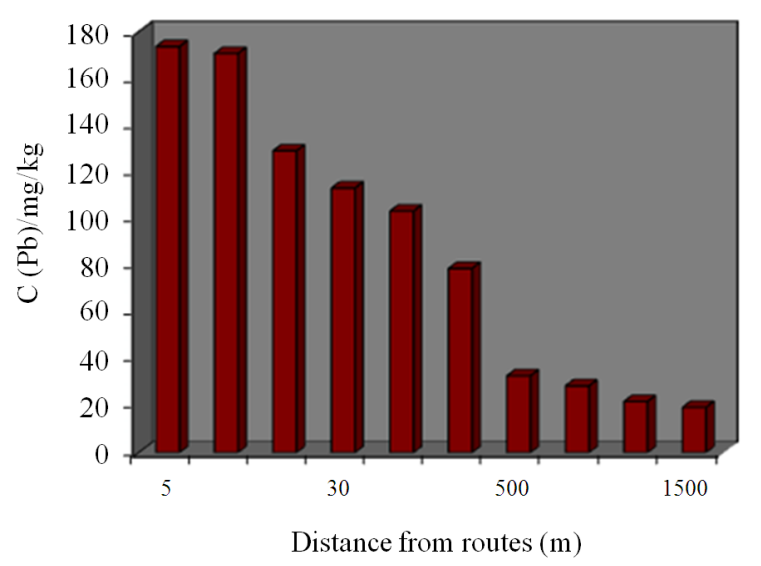

Fig. 1: Lead in samples taken near the highway Prishtina-Skopje (Ferizaj), Kosova

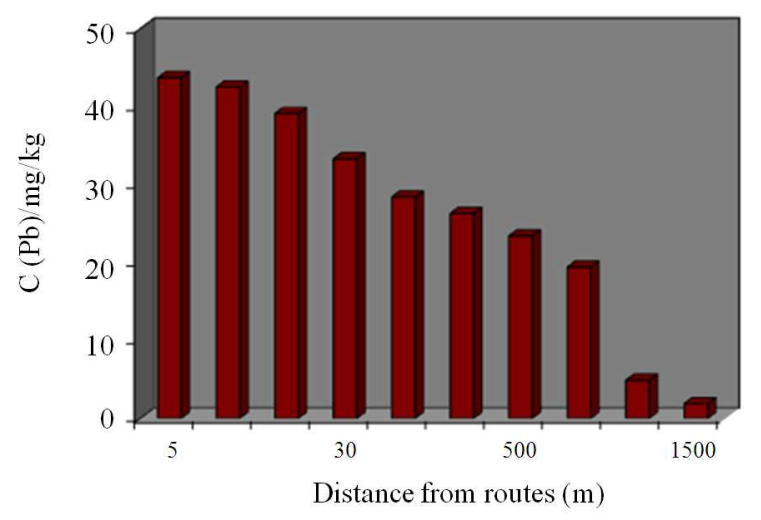

Fig. 2: Lead in samples taken near the highway Prishtina-Gjilan (Artane), Kosova 


\section{CONCLUSION}

Based on obtained results we can conclude that the quantity of Lead is very higher near the highway. Away from highway the quantity of Lead decreases. The concentration of Lead in highway Prishtina-Skopje is higher than in highway Prishtina-Gjilan. This is because the density of cars in highway Prishtina-Skopje is higher than is highway Prishtina-Gjilan.

If the pollution with Lead continues, then in future we will have very danger ecosystem problems. For that is time to do something in way to eliminate this kind of soil pollution and to improve the existing state.

\section{ACKNOWLEDGMENT}

The researchers acknowledge the financial support received from the University of Prishtina, Kosova.

\section{REFERENCES}

Akan, J.C., F.I.A. Abdulrahman, V.O. Ogugbuaja and J.T. Ayodele, 2009. Heavy metals and anion levels in some samples of vegetable grown within the vicinity of challawa industrial area, Kano State, Nigeria. Am. J. Applied Sci., 6: 534-542. DOI: 10.3844/ajassp.2009.534.542

Alloway, B.J., 1994. Heavy Metals in Soils. 2nd Edn., Springer, London, ISBN: 9780751401981, pp: 384.

Cances, B., M. Ponthieu, M. Castrec-Rouelle, E. Aubry and M.F. Benedetti, 2003. Metal ions speciation in a soil and its solution: Experimental data and model results. Geoderma, 113: 341-355. DOI: 10.1016/S0016-7061(02)00369-5

Davis, A., M.V. Ruby and P.D. Bergstom, 1992. Bioavailability of arsenic and lead in soils from the Butte, Montana, mining district. Environ. Sci. Technol., 26: 461-468. DOI: 10.1021/es00027a002
Ge, Y., D. MacDonald, S. Sauvoe and W. Hendershot, 2005. Modeling of $\mathrm{Cd}$ and $\mathrm{Pb}$ speciation in soil solutions by WinHumicV and NICA-Donnan model. Environ. Modell. Software, 20: 353-359. DOI: 10.1016/j.envsoft.2003.12014

Jankiewicz, B., B. Ptaszynski and M. Wieczorek, 2001. Spectrophotometric determination of lead in the soil of allotment gardens in lodz. Polish J. Environ. Stud., 10: 123-126.

Jaunakais, I., B. Tatineni, M. Jaunakais, 2010. New Field Test for Lead $\left(\mathrm{Pb}^{2+}\right)$ in Soil. Int. J. Soil, Sediment Water.

Lee, C.S.L., Xiangdong Li, W. Shi, S.C.N Cheung and I. Thornton, 2006. Metal contamination in urban, suburban and country park soils of Hong Kong: A study based on GIS and multivariate statistics. Sci. Total Environ., 356: 45-61. DOI: 10.1016/j.scitotenv.2005.03.024

Mielke, H., 1999. Lead in the inner cities. Am. Scientist, 87: 62-62. DOI: 10.1511/1999.1.62

Nriagu, J.O. 1979. Global inventory of natural and anthropogenic emissions of trace metals to the atmosphere. Nature, 279: 409-411. DOI: 10.1038/279409a0

Oprea, G., A. Michnea, C. Mihali, M. Senila and C. Roman et al., 2010. Arsenic and Antimony content in soil and plants from baia mare area, Romania. Am. J. Environ. Sci., 6: 33-40. DOI: 10.3844/ajessp.2010.33.40

Oprea, G., C. Mihali, A. Michnea, M. Senila, I. Gogoasa and Z. Vosgan, 2011. Assessment of lead and cadmium content in the soils and plants in industrial area. Am. J. Environ. Sci., 7: 402-408. DOI: 10.3844/ajessp.2011.402.408

Savran, F., K. Demiryurek, O.N. Ozcatalbas, A. Aysegul and I. Boz, 2011. The agricultural extension system and practices in Turkey. Sci. Res. Essays, 6: 1831-1838. 